\section{TYCHO BRAHÉ}

BY the kindness of Dr. Crompton, of Manchester, we are able to publish this week a copy from a photograph of what there is every reason to believe is a contemporary portrait of the great Danish astronomer, Tycho Brahé. This picture is on canvas, and is 3 feet $3 \frac{3}{4}$ inches high, and 2 feet $6 \frac{1}{2}$ inches wide. It represents a man of ruddy complexion, standing and looking forwards. He is bareheaded, has little hair, and that short, of a yellowish colour verging to red. $\mathrm{He}$ has very long moustaches and a short beard. In the right upper corner of the picture (that is, to Brahe's right) there is a curious emblematic design, consisting of a round tapering column springing from a square base, around which at its foot are waves. Over the monument is a canopy suspended by a strong chain, a few links only of which are visible, the top being lost in clouds, and the chain itself has flames playing round it. Two Æolic heads (one on each side) are represented as blowing towards the canopy and column. Lower down, and to the right and left of the column, are two hands (one on each side) holding each a jug from which water flows. Clouds and lightning surround the background, the wrists of the hands holding the jugs, and also the Æolic heads. Round the monument is a label not entirely decipherable with the words: "Stans (tectus?) in solido;" then follows an indistinct word and "ignee.tunda" (sic). "Igne et unda" was, no doubt intended. In the left upper corner, in large and distinct letters, is this inscription: "Effigies Tychonis Brahe, Otton. Da. anno 50 completo quo post diutinum in patria exilium libertati desideratæ divino provisu restitutus est."

Dr. Crompton thinks, correctly we believe, that the inscription referred to Brabés departure from Denmark, and that the "exilium in patria" was an allusion to his residence on his island of Huenna, in his observatory, away from the court for twenty years. The emblematic picture evidently implies that nothing (not all the elements) could destroy the monument he had erected to his reputation by his nbservations, and that they would be protected by Providence.

The portrait then shows Brahé as he was in his fiftieth year, and Dr. Crompton thinks the tenor of the emblems and the inscription seem to be conclusive that the picture was painted after Brahe had left Denmark, most probably between the end of October and the 13 th of December, 1597, and Dr. Crompton conjectures that the portrait may have been painted to be engraved for Brahés "Mechanica."

In connection with this interesting portrait, it may not be inopportune to remind our readers of the main events in Tycho Brahé's life, and of the work on which his fame is grounded.

'Tycho Brabé was born at Knudsthorp, an estate of his ancestors, near Helsingborg, in Sweden, on the Sound, December 14, 1546. Copernicus had been dead two years and a half, Galileo was not born till eighteen years after, and Kepler, with whom Tycho was latterly associated, was about twenty-five years his junior. Tycho's father, Otto Brahé was descended from an ancient Swedish family, and Tycho was the second eldest child, there being altogether five sons and four daughters in the family. Tycho, evidently much against his will, was destined for a military career. After the birth of another son, the father being in straitened circumstances, Tycho was adopted by his uncle, Georye Brahé. Until 1559 he appears to have been educated at home at his uncle's learning reading and writing and Latin, with occasional instruction in poetry and belles-lettres. As it had now been decided that he should quali y himself for some political office in the kingdom of Denmark, Tycho, in April, J 559, was sent to the University of Copenhagen to prepare tor the sudy of law. It seems to have been while pursuing his studies at Copenhagen that Tycho's mind was first strongly attracted to the study of astronomy. An eclipse of the sun was to happen on August $2 \mathrm{r}, 1560$, and Tycho was so struck by the precision with which the various details of the phenomena had been predicted by the astrological almanacs of the time that he was fascinated by, and resolved to master, so wonderful a science as astronomy, more especially, it would seem, that phase of it then universally believed in and cultivated, astrology. The planetary motions seem first to have claimed his attention, and these he studied by means of the Tabulce Bergenses of John Stadius.

In February, 1562, Tycho was sent to Leipsic, under care of a tutor, to study law. For this, however, he had not the smallest inclination, and devoted all his spare time, when not in presence of his tutor, or when the latter was asleep, and all his pocket-money, to becoming master of the science for which he had contracted a passionate devotion. By means of what books he could command, and with a celestial globe about the size of an orange, he studied the heavens nightly, and soon came to discover that the results obtained by himself differed greatly from those of Stadius. "From that moment," says Brewster, "he seems to have conceived the design of devoting his life to the accurate construction of tables, which he justly regarded as the basis of astronomy." For this purpose he set himself to get up a knowledge of mathematics.

So rapid was Tycho's progress in mastering the astronomy of the day, and so skilful already had he become as an observer, that by means of a simple pair of compasses he discovered that both the Alphonsine and Copernican Tables had erred considerably as to the time of the conjunction of Jupiter and Saturn, which took place in August, 1563 . His first instrument seems to have been constructed at the time, a wooden radius, which he got a Leipsic artisan, Scultetus, to devise for him in the manner recommended by Homelius, the professor of mathematics in that city. With this instrument he continued his observations. On his uncle's death, Tycho returned to Denmark about May, 1565, to take possession of the fortune which had been left him. His continued devotion to astronomy greatly offended his friends and relations, who considered such a pursuit as degrading to a noble as trade used to be in this country, and still is in most continental countries. Tycho was so annoyed at the attitude of his friends, that he left Denmark after staying a short time at Witteriberg, took up his residence at Rostock, where he stayed during the years $1566-68$, steadily pursuing his celestial observations. It was in a duel at this place that he lost his nose, which was so ingeniously replaced by a substitute of silver and gold, that few could have detected it to be artificial.

From Rostock Tycho proceeded to Augsburg, where with the help of the brothers Hainzel, he constructed a magnificent quadrant of fourteen cubits radius. It was made of beams of oak bound with iron bands, the arcs being covered with plates of brass, divided into 5,400 lines. To enable him to observe distances, a sextant on a similar scale was constructed, and a wooden globe six feet in diameter was begun ; hitherto his only instrument was the simple radius made at Leipsic. With his new instruments he continued his observations at Augsburg, with rentwed enthusiasm. Tycho returned to his native country in 1571, and found a warm friend in an uncle Steno Bille, who had always taken his nephew's par: against the taunts of his other friends, and who assigned him a part of his own house as an observatory. It was while living thus that one of the most notable events in the life of this great astronomical observer occurred, his discovery, November 11,1572 , of a new star in the constellation of Cassiopeia. This wonderful body probably made its first appearance in the heavens on November 5 , and continued visible for sixteen months, rapidly increasing in brightness till in the second month it surpassed that 
of Jupiter, and was visible at noonday. It then slowly declined, and finally disappeared in March, 1574 . It is curious that in the years 945 and 1264 something similar was observed in Cassiopeia, so that in fact the star observed by Tycho Brahé may be a variable one of long period, and if so may be expected to reappear about the year 1885. The colour of this star, moreover, changed; it was at first white, then yellowish, then reddish ; afterwards bluish, like Saturn, getting duller and duller as it decreased in apparent size. After much persuasion Tycho, in 1572 , published an account of his observations on the new star in a work "De Nova Stella."

Tycho still further offended his relations by marrying a

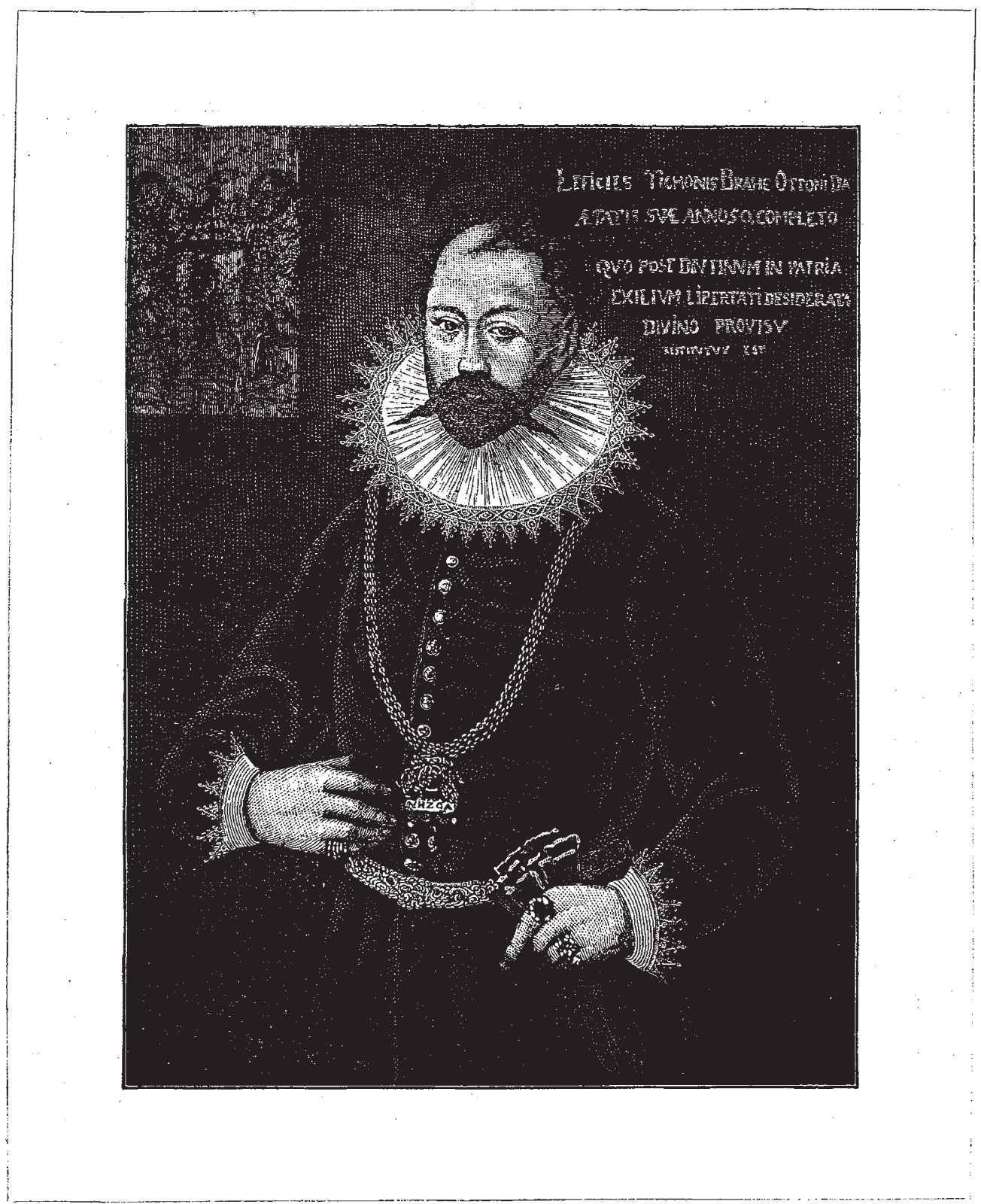

Portrait of Tycho Brahé (from original painting in possession of Dr. Crompton, of Manchester).

peasant girl in 1573 , and shortly after, at the request of the King of Denmark, delivered a course of lectures on astronomy both in its observational and astrological aspects, for in astrology he still continued to believe. After travelling in Germany and Switzerland in 1575 , Tycho returned to Denmark and received from the King, Frederick II, an offer which ought to immortalise the name of that monarch. The King seems always really to have admired the astronomer and estimated highly the pursuits to which he had devoted his life, and now realized it to be his duty, as head of the state, to put the man of science in the most favourable position to carry on researches which were then, as now, essentially unremunerative. In fact, in Frederick's treatment of Tycho Brahé we have an early and munificent, and in its results most successful, instance of the endow ment of research. 
The island of Huen lies in the Sound between Denmark and Sweden, about six miles from the latter and three from the former, and fourteen north-east from Copenhagen. It is somewhat rounded in form, six miles in circumference, and rises from the coast to its centre, where is formed a broad and level table-land. This island the King granted for life to Tycho Brahé, and on it erected a spacious observatory with every convenience for astronomical work and ample accommodation for Tycho's family and servants. A wide space around the central building was inclosed by high substantial walls: in the form of a quadrangle, each angle corresponding to one of the cardinal points, and the centre of each wall extending outwards in the form of a semicircle. At the north and south angles were erected turrets of which one was a printing-office and the other the residence of the servants.

This main building was carefully and elaborately planned. It was about 60 feet square, had on the north and south points two round towers for observations, with

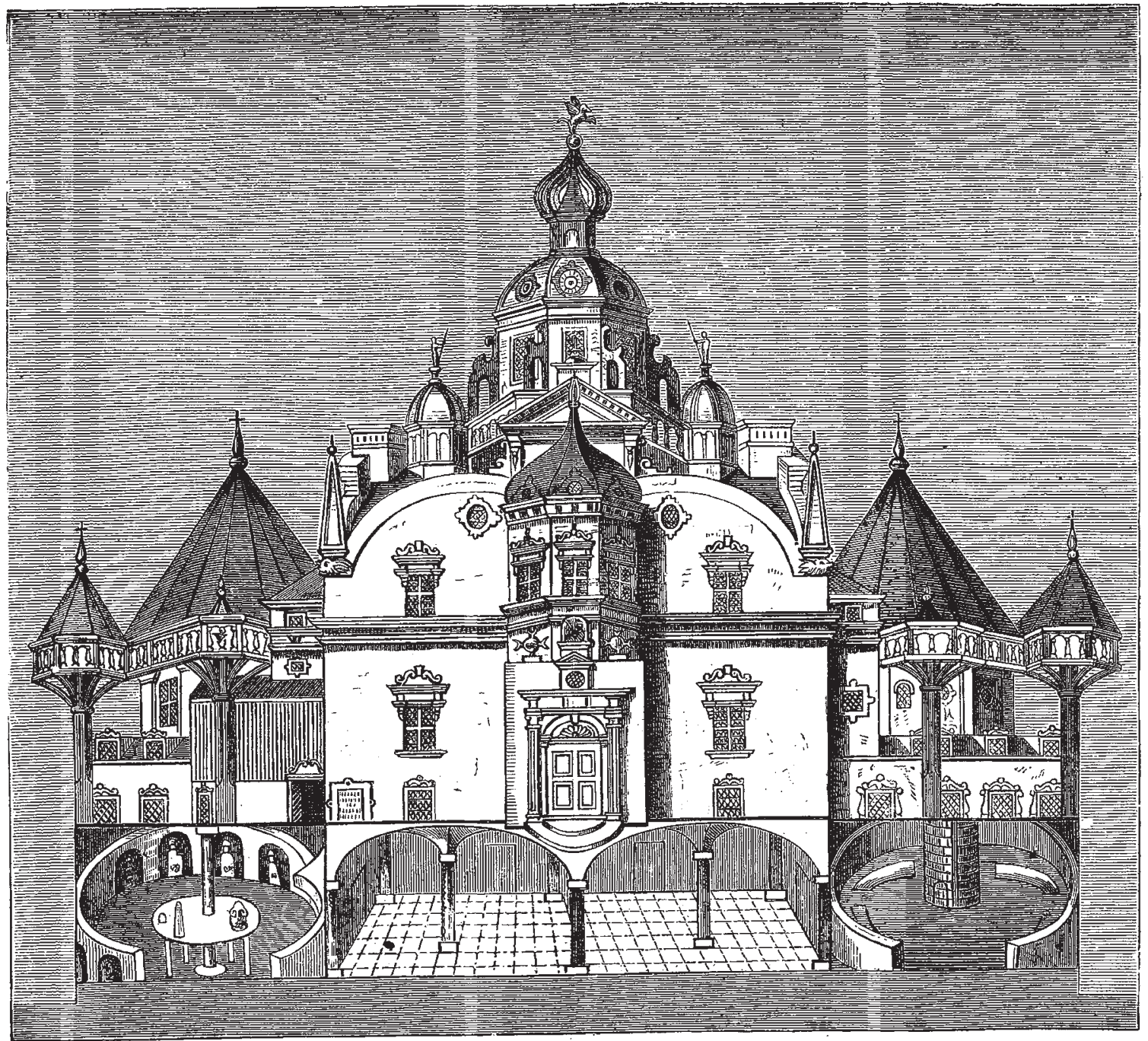

Tycho Brahe's Observatory on the Island of Huẹn.

windows opening to any part of the heavens. $\mathrm{Be}$ sides a museum and a library there was in a subterranean crypt a laboratory with sixteen furnaces, for we ought to say that Tycho devoted much of his time to the alchemical pursuits of the time, mainly, it would appear, in the hope of being able to find in his crucible the fortune he was prepared to spend on his astronomical pursuits. Tycho Brahé needs neither to be defended nor blamed for his belief in astrology and alchemy; it was a universal belief in his time, a belief only got rid of by slow degrees and the thraldom of which no one man could shake off while at its very height, least of all a man with so much reverence for established betiefs as was Tycho Brahé.

A well forty feet deep distributed water to the building by means of syphons. An instrumental workshop stood outside the rampart to the north, and a sort of farmhouse on the south. The foundation-stone of Uraniberg ("the City of the Heavens"), as Tycho called his establishment, was laid on August 6, 1576 .

Large as was Uraniberg, it was found insufficient for the accommodation of all the astronomer's instruments, 
and he therefore erected another, partly underground, for the sake of steadiness and solidity, on a hill a little to the south of the former ; to this he gave the name of Sternberg ("City of the Stars"), which, by an underground passage, was connected with Uraniberg. Both buildings were in a handsome and regular style of architecture, as contemporary pictures testify, and cost the King of Denmark I0O,000 rix dollars $(20,000 \mathrm{l}$.), and Tycho, it is said, an equal sum. Indeed, Tycho's expenses had so reduced his income, that the king gave him an annual pension of 2,000 dollars, an estate in Norway, and a canonry in the church of Rothschild worth $\mathrm{r}, 000$ dollars per annum. Considering the difference between the value of money then and now, these sums for such a purpose may almost be considered munificent beyond example.

The magnificent set of instruments with which Tycho stocked the buildings were all made under his own superintendence, and according to his own designs, many of them having the merit of original inventions. For number, workmanship, and design, they were unequalled at the time. The following is a list of these instruments as given in Sir David Brewster's excellent memoir of Brahe, in "Martyrs of Science," on which the present notice is mainly based :-

\section{In the South and greater Observatory.}

x. A semicircle of solid iron covered with brass, four cubits radius.

2. A sextant of the same materials and size.

3. A quadrant of one and a half cubits radius, and an aximuth circle of three cubits.

4. Ptolemy's parallactic rules, covered with brass, four cubits in the side.

5. Another sextant.

6. Another quadrant, like No. 3 .

7. Zodiacal armillaries of melted brass, and turned out of the solid, of three cubits in diameter.

Near this observatory there was a large clock with one wheel two cubits in diameter, and two smaller ones which, like it, indicated hours, minutes, and seconds.

\section{In the South and lesser Observatory.}

8. An armillary sphere of brass, with a steel meridian, whose diameter was about four cubits.

\section{In the North Observatory.}

9. Brass parallactic rules, which revolved in azimuth above a brass horizon, twelve feet in diameter.

10. A half sextant, of four cubits radius.

Ir. A steel sextant.

12. Another half sextant with steel limb, four cubits radius.

3. The parallactic rules of Copernicus.

14. Equatorial armillaries.

15. A quadrant of a solid plate of brass, five cubits in radius, showing every ten seconds.

16. In the museum was the large globe made at Augsburg.

\section{In the Sternberg Observatory.}

7. In the central part, a large semicircle, with a brass limb, and three clocks, showing hours, minutes, and seconds.

18. Equatorial armillaries of seven cubits, with semi-armillaries of nine cubits.

19. A sextant of four cubits radius.

20. A geometrical square of iron, with an intercepted quad. rant of five cubits, and divided into fifteen seconds.

21. A quadrant of four cubits radius, showing ten seconds, with an azimuth circle.

22. Zodiacal armillaries of brass, with steel meridians, three cubits in diameter.

23. A sextant of brass, kept together by screws, and capable of being taken to pieces for travelling with. Its radius was four cubits.

24. A movable armillary sphere, three cubits in diameter.

25. A quadrart of solid brass, one cubit radius, and divided into minutes by Nonian circles.

26. An astronomical radius of solid brass, three cubits long. 27. An astronomical ring of brass, a cubit in diameter. 28. A small brass astrolabe.
In the island of Huen Tycho resided and carried on his astronomical work for twenty-one years. The island itself was at the time fertile and well cultivated. The astronomer was virtually monarch of all he surveyed. He seems to have been loved by his subjects, and to have led a life of peaceful research and healthy contentment which any man of science of the present day might envy. Teaching was no condition of his tenure of the island and observatory, but his fame, which spread far and wide, attracted numbers of pupils eager to study under the great astronomer. Some of these were trained at the expense of the king, others were sent by different academies and cities, and several were maintained by the astronomer himself. Distinguished visitors were constantly arriving to do homage to the great man, and among these was our own James I., then, however, only James VI. of Scotland. This was in the year I 590, when the king was in Denmark to wed the Princess Anne. He spent eight days at Uraniberg, discussing various subjects with Tycho, and carefully examining all the instruments. He was so much surprised by what he saw and heard, that he granted the astronomer liberty to publish his works in England during seventy years.

Tycho Brahé might have peaceably ended his days in his pleasant island home, had his great patron Frederick II. lived; he died jn April, I 588, and a new king, Christian IV., arose "who knew not Joseph," or at least cared

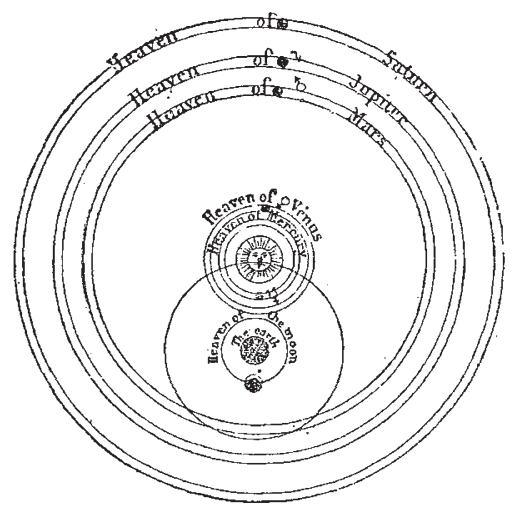

Tycho Brahé's System

nothing for him and his work. While Frederick reigned his courtiers of course, and many of them sincerely, professed to be passionately fond of astronomy; but as might be expected, Frederick's munificent kindness 10 Tycho made him many envious enemies. He continued to be tolerated for several years after the death of Frederick, but at last the young king's mind became so poisoned against Tycho by some of the courtiers, that he was deprived of his pension, his estate in Norway, and his canonry. With a wife, five sons, and four daughters, it was scarcely possible for him now to continue his work, but he stayed on till the spring of $\mathrm{I} 597$, when he removt $\mathrm{d}$ to Copenhagen. His persecution was brought to a crisis by a personal attack made on himself at the instigation of his chief enemy, the President of the Council, Waichendorp, in which one of his servants was injured. Tycho had the spirit to retaliate on his assailants, but almost broken-hearted he resolved to leave a country which had got tired of the glory of its greatest citizen, and which had nothing for him but persecution and insuît. Fortunately he had many friends abroad among the nobles and princes of Europe. Among these was Count Henry Rantzau, who lived at the Castle of Wandesburg, near Hamburg, and who invited Tycho to take up his abode with him. Here then, with all his family, he went in the end of 1597 , and here he wrote his "Astronomiæ instauratæ Mechanica," containing an account, with illustrations, of his various 
instruments and their uses, and also of his chemical labours. This work also contains views and plans of his observatory at Huen, and in the British Museum is an original copy presented by Tycho to his friend, Dr. Thaddeus Haggecius ab Hayck, Chief Physician to the

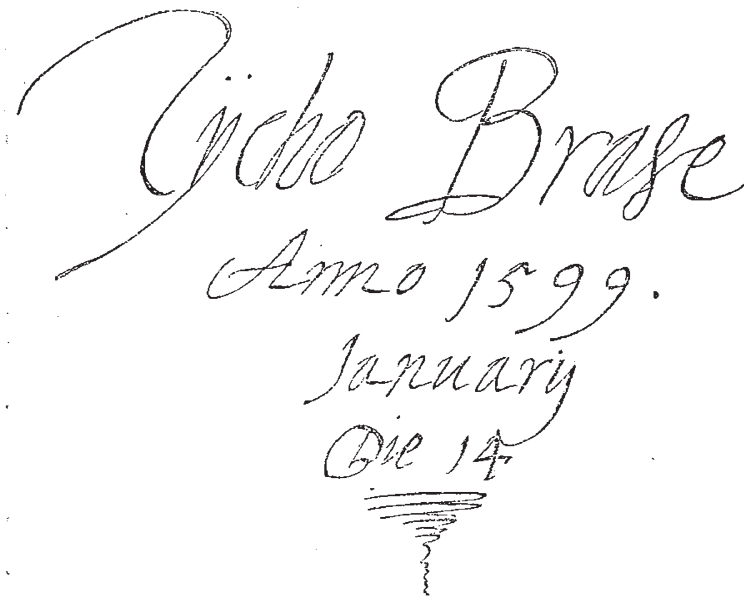

Kingdom of Bohemia, and bearing the fine autograph which we here reproduce (one-half the size of the original). The work was printed at Wandesburg in I 598, and a copy, along with a MS. catalogue of 1,000

\section{0 \\ ARMILLE ZODIACALES}

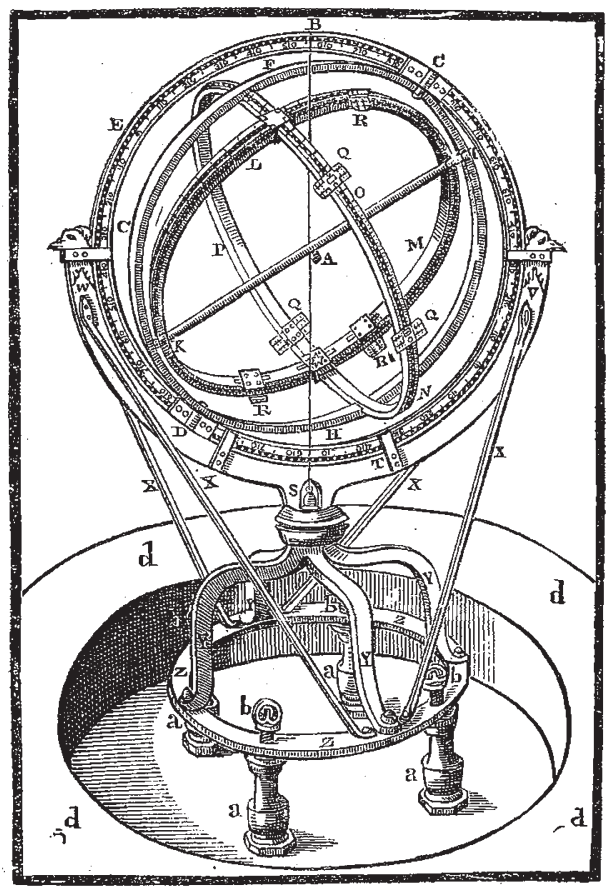

Ecliptic Astrolabe ( $T$, cho Brahé) similar to that used by Hipparchus.

stars, was sent to the Emperor Rudolph II., a great lover of alchemy and astronomy. The result was an invitation to Tycho to go to Prague, with an assurance that he would receive the warmest welcome. Thither he went with his family in 1599 , and most of his fine set of instruments followed soon after, An annual pension of 3,000 crowns was bestowed upon him, and the castle of Benach given him for residence, though in the beginning of 160 I he removed into Prague, to the house of his late friend Curtius, which the Emperor had purchased and presented to the astronomer. It was at this period that Kepler, then about twenty-nine years of age, lived and worked with Tycho, who procured for him the post of imperial mathematician, for which; however, Kepler never seems to have received any income.

Notwithstanding the munificent treatment of Rudolph, Tycho's misforturies in Denmark must have told seriously on his health, and his enid was near. $\mathrm{He}$ had a serious attack on October 13 , which so told on his weakened constitution, that although the immediate cause was removed, his strength failed him, and he expired on the

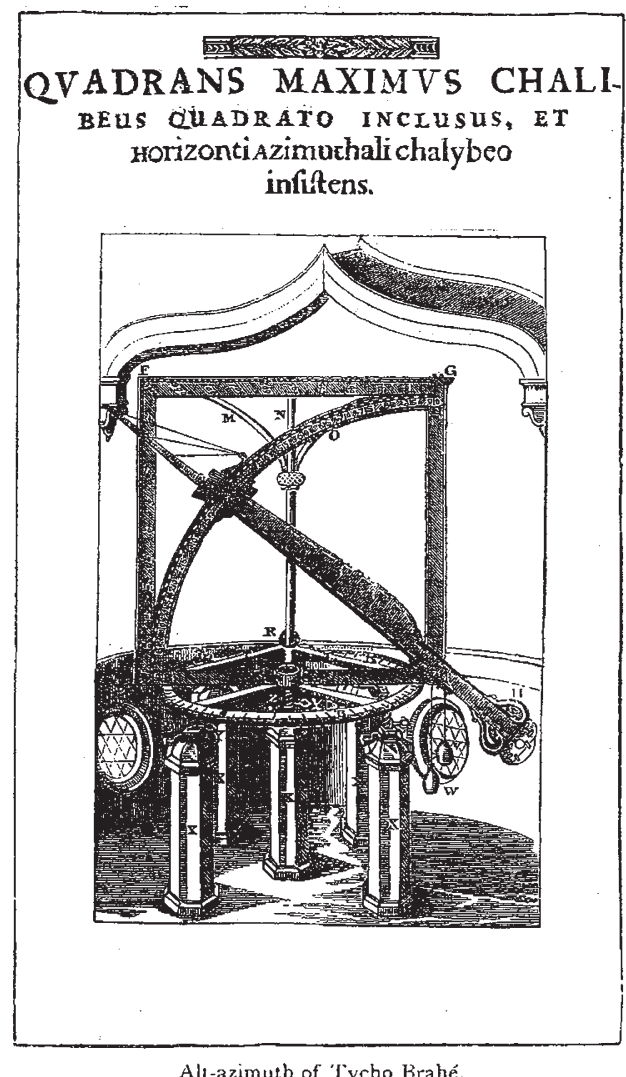

$24^{\text {th }}$ of the same month, within two months of completing his fifty-fifth year.

As to Tycho Brahés work, we cannot do better than give the following summary by Sir David Brewster :-

"As a practical astronomer, Tycho has not been surpassed by any observer of ancient or of modern times. The splendour and number of his instruments, the ingenuity which he exhibited in inventing new ones and in improving and adding to those which were formerly known, and his skill and assiduity as an observer, have given a character to his labours, and a value to his observations, which will be appreciated to the latest posterity. The appearance of the new star in 1572 led him to form a catalogue of 777 stars, vastly superior in accuracy to those of Hipparchus and Ulugh Beig. His improvements on the lunar theory were still more valuable. He discovered the important inequality called the variation, and likewise the annual inequality which depends on the position of the earth in its orbit. He discovered, also, 
the inequality in the inclination of the moon's orbit, and in the motion of her nodes. He determined with new accuracy the astronomical refractions from an altitude of $45^{\circ}$ down to the horizon, where he found it to be $34^{\prime}$; and he made a vast collection of observations on the planets, which formed the groundwork of Kepler's discoveries, and the basis of the Rudolphine Tables."

\section{MINIATURE PHYSICAL GEOLOGY}

T

HERE have appeared from time to time in the columns of NATURE, interesting and instructive letters on the subject of Miniature Physical Geology. May I be allowed to continue this subject, by pointing out a few lessons which may be learnt during spare halfhours on Ramsgate Sands.

Not far to the east of the harbour, there bubbles up a little stream, which, when the tide is low, flows for a considerable distance over the sands before it reaches the sea. Small as it is, this offers an excellent miniature examiple of a large river, and from it several things may be learnt. In the first place the river, when carefully watched, is seen repeatedly, and with more or less rapidity, to change its course. This is effected by the deflection, from some cause or other, of the inain course of the stream against one bank; the result of which is that the bank is forced to recede, and, as it does so, it ceases to be a shelving slope, and becomes a tiny cliff of greater or less relative height. This bank continues to be rapidly undermined by the action of the stream, and the upper portions, now and again, topple over, with a little splash, into the water, in a manner with which those who have travelled on the Mississippi are well acquainted. In this way a bold curve is formed, which increases in length downstream.

In the meanwhile, on the opposite shore of the river, sand is deposited, and, as the river cuts its way downwards, this portion is left high and dry.

Butt, ere long, the deep water channel shifts-often rapidly, and without apparent cause-and the miniature river tends to resume a straight course; it recedes from its bank cliffs, and soon a träct of comparatively level dry land separates these banks from the stream. After advancing, however, for a while in this direction, until it there forms a curve similar to the one described above, it once more swings in the direction of its former course; until, by a continuance of the same processes, a broad valley is formed, with beautifully-marked river terraces on either side, showing the length of swing of the river on each occasion that it oscillates to and fro.

In the midst of the stream sand islands are from time to time formed, partly by the deepening of the main channel on one side or the other ; but; no sooner has the sand of which they are composed become dry, than the treacherous stream ccmmences the destruction of that Which itself had prodiced.

This is exactly what is continually taking place in the Delta areas of most great rivers. In the Pará branch of the Amazions a large island (Parraqueet Island) has, within the last quarter of a century, completely disappeared. The lhla Nova has arisen, and is now covered with a luxuriant vegetation.

During the repeated changes in the course of our miniature river, it is possible to watch the deposition of a layer of coarse sand on the partially-eroded surface of a bed of finer material, and it is interesting and instructive to notice how great a body of the coarse material is dragged along the bottom. Even in the most sluggish of my miniature streams the sand-grains might be seen rolling over and over each other as they travelled seawards.

In the more muddy flats of Pegwell Bay, I, on one occasion, had an oppoitunity of witnessing the formation of that which is known on the Mississippi as a "cut-off" The miniature stream bent round in a great loop, and as the flow of the water caused the concave banks to recede, the loop was gradually converted into a circle of water, and, the main stream flowing through the shortest course left a "horse-shoe" lake, which was in time almost completely shut off from the miniature river.

Perhaps one of the most interesting of these spare half-hours may be spent in watching the formation of deltas. Numbers of these miniature rivers flow into pools, which are miniature seas or lakes. I have often seen one of the streams in the course of an hour fill up a considerable bay, and push its delta far out to sea. The grains of sand, when they come to rest in the pool, form a slope of very constant angle, which, by a number of measurements, 1 found to be $40^{\circ}$ for coarse sand, and $34^{\circ}$ for fire sand, the average angle being $36^{\circ}$. By watching the advance of the delta, the formation of false bedding may be seen in actual progress. But these pools, ot miniature seas, which lie in depressions in the chalk, offer a field for the study of marine denudation: Orie may see, for instance, the waves advancing over a newly: formed delta, planing off the upper portion, and forming tiny cliffs of delta material, but leaving the deeper parts of the slope of the deposit intact.

Again, during gentle and steady breezes one may see the formation of drift-currents. I remember watching with interest such a current, which flowed between tiny chalk cliffs through the straits which separated two miniature seas; the most instructive point being that the finer grains of sand at the bottom of the straits $s_{j}$ where the water was some 7 inches deep, were rolling over each other in such a manner as to prove the existence of an under-current setting in the opposite direction to that in which the surface-current was flowing.

There are many other lessons which may be learntsuch as the formation of fan-deposits (similar to those so plentiful in the Rhone valley and elsewhere in Switzerland), which are formed at the foot of the miniature chalk mountains. that stand out from the sand; and the stoppage of the sand ripples, or miniature sand dunes; by the tiniest stream, reminding us of the way in which the Nile has preserved Egypt from total obliteration by this material ; but I have already occupied enough of your space.

My object in drawing attention to such matters of ordinary observation is to induce students of physical geology to go out and observe these things for themselves. If after a morning's study of Lyell's "Principles," the young geologist will devote an hour's careful observation to miniature physical geology, with sketch and note-book in hand, he will find that his conceptions have a reality and a solidity which could not have been evolved in the study at home, while at the same time he will find it more easy to follow, when he shall have the opportunity, the workings of nature on a grander scale.

\section{LLOYD MORGAN}

\section{TESTIMONIAL TO MR. DARWIN-EVOLU-} TION IN THE NETHERLANDS

WE have great pleasure in printing the following correspondence :-

\section{To the Editor of NATURE.}

Utrecht, February 20,1877

On the sixty-eighth birthday of your great countryman, Mr. Charles Darwin, an album with 217 photographs of his admirers in the Netherlands, among whom are eightyone Doctors and twenty-one University Professors, was presented to him. To the album was joined a letter, of which you will find a copy here inclosed, with the answer of Mr. Darwin. 